\title{
Effect of vitamin E supplementation on growth performance, carcass characteristics and intramuscular fatty acid composition of Longissimus dorsi muscle in 'Tan' sheep
}

\author{
Tianzhang Zhao, ${ }^{1,2}$, Hailing Luo ${ }^{1 *}$, Yuwei Zhang ${ }^{1}$, Kong Liu' ${ }^{1}$, Huina Jia ${ }^{1}$, Yanfei Chang ${ }^{1}$, Lijuan Jiao ${ }^{1}$, \\ and Weimin Gao ${ }^{1}$
}

The beneficial effects on meat quality of adding vitamin E to diets have been extensively studied in cattle and lamb. However, how supplemental vit E affects the performance and meat quality of 'Tan' sheep has not been reported. Thirtyfive male lambs of 'Tan' sheep (20-30 d after weaning) with similar body weight were randomly divided into five groups of seven each to receive a basal diet plus five levels of vit E supplementation: 0 (control group, CG), 20, 100, 200, and 2000 IU $\mathrm{d}^{-1}$ lamb ${ }^{-1}$. The results showed: 1) no differences were observed in animal growth performance between CG and vit E treated groups (VG) $(P>0.05)$; 2) vit E supplementation levels over $200 \mathrm{IU} \mathrm{d}^{-1}$ lamb $^{-1}$ dramatically suppressed subcutaneous fat deposition and similarly that above $100 \mathrm{IU} \mathrm{d}^{-1}$ lamb $^{-1}$ considerably reduced drip loss and $\mathrm{pH} 24 \mathrm{~h}$ of Longissimus dorsi (LD) muscle in VG lambs compared to those of CG $(P<0.01)$, but with no significant effect on other carcass characteristics $(P>0.05) ; 3)$ although vit E supplementation generally did not affect the fatty acid composition of intramuscular lipids in LD muscle, the percentage of n-6 polyunsaturated fatty acids (PUFA) and the ratio of n-6/n-3 PUFA were significantly enhanced $(P<0.05)$ and an increasing tendency $(P<0.1)$ for both total PUFA proportion and the ratio of PUFA/saturated fatty acids (SFA) was also observed in 'Tan' sheep lambs treated with vit E. In conclusion, vit E supplementation of male 'Tan' sheep lambs did not influence growth performance, significantly reduced subcutaneous fat deposition, drip loss, $\mathrm{pH}$ $24 \mathrm{~h}$ and tended to improve fatty acid profile of LD muscle.

Key words: Carcass characteristics, growth performance, vitamin E.

\section{INTRODUCTION}

In 1922, Evans and Bishop firstly discovered that vitamin $\mathrm{E}$ in wheat (Triticum aestivum L.) germ oil played an important role on reproduction of rats. After that, a number of research studies were conducted to study on vitamin $\mathrm{E}$ in various areas of biology. Recently, in addition to the commonly recognized role of vitamin E as a highly effective antioxidant in lipid oxidation (Dufrasne et al., 2000), ruminant nutritionists also found that supplemental vit $\mathrm{E}$ had positive effects on the performance of feedlot ruminant and the quality of their meat products (Turner et al., 2002; Macit et al., 2003b; Álvarez et al., 2008). Compared with beef, lamb probably has a higher antioxidant requirement to extend its shelf life and that is because lamb contains more long-chain poly unsaturated fatty acids (PUFA) (International Institute for Refrigeration, 1964; Enser et al., 1996), which is

${ }^{1}$ China Agricultural University, College of Animal Science and Technology, Beijing, 100193, P.R. China.

*Corresponding author (luohailing@cau.edu.cn).

${ }^{2}$ Bio-Technology Department, Wulanchabu Vocational College, Wulanchabu, 012000, P. R. China.

Received: 17 June 2013.

Accepted: 17 October 2013.

doi: $10.4067 /$ S0718-58392013000400005 susceptible to oxidation and is considered to be one of the main factors to induce meat to oxidative rancidity when meat is exposed for a long time on a shelf (Sherbeck et al., 1995). Vitamin E, usually as all-rac- $\alpha$-tocopherol acetate, is a highly effective chain-breaking antioxidant which can reduce the susceptibility of muscle to lipid oxidation (Salvatori et al., 2004). The beneficial effects on meat quality of adding vit $\mathrm{E}$ to diets have been extensively studied in lamb (Álvarez et al., 2008; Kasapidou et al., 2009; 2012) and the mechanism for that may be related to two facts: (1) vit E could exert a protective effect on meat PUFA against peroxidation. Morrisey et al. (1994) indicated that the presence of vit $\mathrm{E}$ within muscle cell membranes reduced lipid oxidation, improving the quality characteristics of meat such as color, flavor, texture and nutritional value, and also extending its shelf-life. (2) vit E could somehow modify the biohydrogenation pathways of dietary PUFA in rumen and consequently indirectly improve the fatty acid composition of meat products. Pottier et al. (2006) reported that inclusion of dietary vit $\mathrm{E}$ at $12000 \mathrm{IU} \mathrm{d}^{-1}$ could result in a shift in rumen PUFA biohydrogenation toward production trans-11 C18:1 rather than trans-10 C18:1. In addition, Hou et al. (2012) found that vit $\mathrm{E}$ supplementation could accelerate the ruminal biohydrogenation of $\mathrm{C} 18: 1$ and affect conjugated linoleic acid (CLA) level in rumen fluid in vitro. 
Our previous studies had proved that moderate level $\left(200 \mathrm{IU} \mathrm{d}^{-1} \mathrm{lamb}^{-1}\right)$ of vit E supplementation could improve fatty acid composition of LD muscle in 'Boer' goat (Luo et al., 2010) and 'Aohan' fine-wool sheep (Ge et al., 2011). 'Tan' sheep, a special local sheep breed, is celebrated for its meat that is authorized by the government as a geographically symbolic product (AGI2008-07-00061) in Ningxia province, China. However, it is very limited for the available data to evaluate the effects of supranutritional supplementation of vit $\mathrm{E}$ on meat quality of 'Tan' sheep.

Therefore, the objectives of the present study were to investigate the effects of increasing dietary concentrations of vit $\mathrm{E}$ on growth performance, carcass characteristics, and intramuscular fatty acid composition of Longissimus dorsi (LD) muscle in Tan sheep lambs.

\section{MATERIALS AND METHODS}

\section{Animals}

'Tan' sheep is a particular fur-purpose breed of sheep raised mainly in the Ningxia Hui Autonomous Region, northwest of China, with high quality meat under unfavorable environmental and feeding conditions, and its products are often exported to Middle Eastern countries. Accordingly, the 'Tan' sheep industry is of significant economic importance for a large area of northwestern China.

The work described in this paper was conducted in accordance with the requirements of the Animal Care and Use Committee of China Agricultural University.

\section{Experiment design and dietary treatments}

Thirty-five male lambs of 'Tan' sheep at the age of 4-mo \pm $10 \mathrm{~d}$ (i.e., 2 wk after weaning, initial body weight; BW = $18.75 \pm 1.62 \mathrm{~kg})$ individually housed in shaded pens (1.0 $\mathrm{m} \times 1.1 \mathrm{~m})$ and allowed visual contact with each other and water was supplied ad libitum. Lambs were assigned on the basis of body weight (BW) to one of five dietary treatments being a control diet without added vit E (CG) and four additional diets (VG) containing 20, 100, 200, and $2000 \mathrm{IU} \mathrm{d}^{-1}$ lamb $^{-1}$ of vit E ( $\alpha$-tocopheryl acetate), respectively. These dose levels were $0,1,5,10$, and 100 times that of the NRC (1985) feeding standard, which was chosen according to our previous studies (Luo et al., 2010; Yan et al., 2010; Ge et al., 2011; Liu et al., 2012).

All diets with roughage to concentrate ratio at 50:50(DM base) were formulated to meet all nutrient requirements for the growing lambs (NRC, 1985). Experimental diets were mixed biweekly to minimize oxidation of vit E. Upon mixing, feed samples were collected and saved (-20 ${ }^{\circ} \mathrm{C}$ ) for later analysis according to procedures of AOAC (1990) for DM, crude protein (CP) and ether extract (EE). Additionally, samples were analyzed for neutral detergent fiber (NDF) and acid detergent fiber (ADF) according to Van Soest et al. (1991) to determine dietary composition (Table 1). The experiment lasted for $130 \mathrm{~d}$, first $10 \mathrm{~d}$ for adaptation and the following $120 \mathrm{~d}$ for experiment.

Lambs were weighed before the morning feeding at the beginning and, thereafter, weekly throughout the study. Lambs average daily gain (ADG) was calculated by subtracting initial from final $\mathrm{BW}$ and then dividing by the duration of study. Lambs were offered the diets twice daily at 07:00 $\mathrm{h}$ and 17:00 $\mathrm{h}$, with the sequence of roughage firstly and then concentrate. Lambs had ad libitum access to feed and free access to clean water throughout the study. The amounts of feed offered and refused were recorded daily for each lamb to determine feed intake.

\section{Slaughtering procedure and carcass characteristics}

At the end of the experiment, all animals were slaughtered at a commercial abattoir after being fasted for $24 \mathrm{~h}$ as reported previously (Ponnampalam et al., 2001). Carcasses were immediately weighed to obtain the hot carcass weight. Then, carcasses were cut into halves along the midline and the right sides were dissected and measured for total lean, subcutaneous fat, fat depth, and rib-eye area as described by Awawdeh et al. (2009). Longissimus dorsi (LD) muscle $\mathrm{pH}$ was measured between the $12^{\text {th }}$ and $13^{\text {th }}$ ribs $45 \mathrm{~min}$ and $24 \mathrm{~h}$ postmortem using a portable pH meter (Schott L 6880, Lab Star pH, Mainz, Germany). Dressing proportion was calculated as the hot-carcass weight proportion of the fasted BW. Loin samples (25 mm thick) were collected $24 \mathrm{~h}$ postmortem and kept at 4 ${ }^{\circ} \mathrm{C}$ until drip loss analysis. Drip loss was determined 48 $\mathrm{h}$ postmortem via the bag method (Lanza et al., 2003). Finally, Longissimus thoracis (LT) muscle was then cut out from the left side of each carcass and samples were taken and kept at $-20{ }^{\circ} \mathrm{C}$ until analyzed for intramuscular lipids and fatty acid composition of LD muscle.

\section{Chemical analyses}

Intramuscular lipids. The content of intramuscular lipids in LD muscle was determined as crude fat in a Soxhlet apparatus by extraction with petroleum-ether as the fat solvents (XT 15i, ANKOM Technology, Macedon, New York, USA).

Table 1. Ingredients and chemical composition of experimental diets.

\begin{tabular}{|c|c|c|c|}
\hline Ingredients (DM basis) & Ratio (\%) & Chemical composition & of DM \\
\hline Corn silage & 50.00 & Metabolizable energy, $\mathrm{MJ} \mathrm{kg}^{-1(\mathrm{~b})}$ & 8.95 \\
\hline Corn & 27.81 & Crude protein, $\%$ & 12.30 \\
\hline Soybean meal & 13.00 & Ether extract, \% & 5.08 \\
\hline Wheat bran & 4.93 & Neutral detergent fiber, $\%$ & 48.77 \\
\hline Shelled sunflower meal & 2.11 & Acid detergent fiber, $\%$ & 33.89 \\
\hline Sodium chloride & 0.68 & Vitamin E, $\mathrm{mg} \mathrm{kg}^{-1(\mathrm{c})}$ & 3.42 \\
\hline Calcium carbonate & 0.23 & $\mathrm{Ca}, \%$ & 0.51 \\
\hline Calcium hydrophosphate & 0.11 & $\mathrm{P}, \%$ & 0.36 \\
\hline Premix $^{\mathrm{a}}$ & 1.13 & & \\
\hline
\end{tabular}

a'Content per kilogram of premix: 100000 IU vitamin A, 20000 IU vitamin D3, 60 IU vitamin E, $1 \mathrm{~g} \mathrm{Fe}, 1 \mathrm{~g} \mathrm{Mn}, 0.78 \mathrm{~g} \mathrm{Zn}, 0.27 \mathrm{~g} \mathrm{Cu}, 0.012 \mathrm{~g} \mathrm{Se}, 0.01 \mathrm{~g} \mathrm{I}$.

${ }^{\mathrm{b}}$ All values are analyzed except metabolizable energy; metabolizable energy content was calculated based on tabular values (NRC, 1985).

cLevels indicated are background levels without the addition of synthetic $\alpha$-tocopheryl acetate. 
Fatty acids. The measurement of intramuscular fatty acid composition was conducted in the Ministry of Agriculture Feed Industry Center (MAFIC) of China. The extraction and transmethylation of fatty acids from LD muscle were carried out following the procedures provided by MAFIC. The remaining portions of LT were minced and freezedried, then samples weighing about $0.15 \mathrm{~g}$ were placed into a screwed tube and homogenized with $4 \mathrm{~mL} \mathrm{1:10} \mathrm{(v/v)}$ mixture of chloroacetyl-methanol (now with the current use, slowly put 1 chloroacetyl into 10 methanol to prevent splash explosion). After adding $1 \mathrm{~mL}$ internal standard $\left(1 \mathrm{mg} \mathrm{mL}^{-1}\right.$ C11:0) and $1 \mathrm{~mL}$ hexane, the screwed tubes were put into $80^{\circ} \mathrm{C}$ water bath for standing $2 \mathrm{~h}$ and thereafter were cooled down at room temperature. The mixture was added with 5 $\mathrm{mL} 7 \% \mathrm{~K}_{2} \mathrm{CO}_{3}$, well oscillated and centrifuged in $1200 \mathrm{r}$ $\mathrm{min}^{-1}$ for $5 \mathrm{~min}$. About $1 \sim 2 \mathrm{~mL}$ supernatant was transferred into injection vial to be analyzed on gas chromatography, which was performed on a gas chromatograph (GC-6890N, Agilent, Santa Clara, California, USA) apparatus equipped with a DB-23 type capillary column $(60 \mathrm{~m} \times 250 \mu \mathrm{m} \times$ $0.25 \mu \mathrm{m})$ and flame ionization detector. Direct injection on the column was performed with $1 \mu \mathrm{L}$ samples. The GC conditions were: $\mathrm{N}_{2}$ as the carrier gas with a flow rate of $2 \mathrm{~mL} \mathrm{~min}^{-1}$; split mode injection 20:1; injector temperature $260{ }^{\circ} \mathrm{C}$ and flame ionization detector temperature $270{ }^{\circ} \mathrm{C}$; initial oven temperature $180{ }^{\circ} \mathrm{C}$ for $15 \mathrm{~min}$, then increased at $1.5^{\circ} \mathrm{C}$ per min to $220^{\circ} \mathrm{C}$, and held at $220^{\circ} \mathrm{C}$ for $10 \mathrm{~min}$; the oven temperature was $190{ }^{\circ} \mathrm{C}$. Fatty acids were identified by comparison of the retention times with known standard mixtures of fatty acid methyl esters (NU-VHEK, USA) and quantified by adding methyl-undecanoic acid as an internal standard prior to hydrolysis of tissues or lipid extracts.

Results were expressed as $\mathrm{mg} \mathrm{g}^{-1}$ of muscle for total fatty acids (TFA) and as percentage of TFA for each fatty acid. The proportion of PUFA (C18:2n-6; C18:3n-6; C18:3n-3; C20:3n-6; C20:4n-6; C20:5n-3; and C22:6n-3), monounsaturated (MUFA) (C14:1n-7; C16:1n-7; C18:1n-9; C18:1n-11; and C20:1n-9) and saturated (SFA) (C8:0; C10:0; C12:0; C13:0; C14:0; C15:0; C16:0; C17:0; C18:0; C20:0; C21:0; and C22:0) fatty acid contents were calculated.

\section{Statistical analysis}

The individual animal was the experimental unit. Data were analyzed according to $t$ test for determination of differences between control and vitamin treatment groups, and ANOVA for determination of differences among all treatments using the GLM procedure of SAS (SAS Institute, 2002) with concentration of dietary vit $\mathrm{E}$ as the independent variable. Statistical differences between means were tested using Duncan's multiple range tests (Duncan, 1955).

\section{RESULTS AND DISCUSSION}

\section{Animal performance}

Growth performance parameters of lambs from CG and VG are shown in Table 2. The initial weight, final weight, daily DM intake per animal in a day (DMI) and feed conversion ratio did not differ between control and vitamin treatment groups. The ADG were found to be $122.02 \mathrm{~g}$ for lambs from CG and 126.19, 110.12, 109.52, and $107.74 \mathrm{~g}$ for lambs from VG group corresponding to vit $\mathrm{E}$ supplementation level of 20, 100, 200, and 2000 $\mathrm{IU} \mathrm{d}^{-1} \mathrm{lamb}^{-1}$, respectively. This result indicated that vit $\mathrm{E}$ supplementation levels over $100 \mathrm{IU} \mathrm{d}^{-1} \mathrm{lamb}^{-1}$ tended to suppress the growth of Tan sheep lambs compared with those fed a control diet $(P<0.1)$, which is consistent with the finding of Wulf et al. (1995), who reported that lambs fed on concentrates added $1000 \mathrm{mg}$ all-rac- $\alpha$-tocopheryl acetate $\mathrm{d}^{-1}$ had a lower weight gain $(P<0.05)$.

Vitamin E plays an important role in the development

Table 2. Effect of vitamin E supplementation on performance of 'Tan' sheep lambs.

\begin{tabular}{|c|c|c|c|c|c|c|}
\hline \multirow[b]{2}{*}{ Performance ${ }^{3}$} & \multicolumn{6}{|c|}{ Dietary vitamin $E$ added levels $\left(\mathrm{IU} \mathrm{d}^{-1} \text { lamb }^{-1}\right)^{1}$} \\
\hline & 0 (CG) & 20 (VG20) & 100 (VG100) & 200 (VG200) & 2000 (VG2000) & $p^{2}$ \\
\hline \multirow[t]{3}{*}{$\mathrm{DMI}, \mathrm{kg} \mathrm{d}^{-1}$} & $0.75 \pm 0.028$ & $0.72 \pm 0.091$ & $0.73 \pm 0.033$ & $0.75 \pm 0.084$ & $0.72 \pm 0.056$ & NS \\
\hline & CG & $0.75 \pm 0.028$ & $0.75 \pm 0.028$ & $0.75 \pm 0.028$ & $0.75 \pm 0.028$ & \\
\hline & $P$ & NS & NS & NS & NS & \\
\hline \multirow[t]{3}{*}{ Initial BW, $\mathrm{kg}$} & $16.14 \pm 1.82$ & $16.21 \pm 1.82$ & $16.29 \pm 1.75$ & $16.21 \pm 1.65$ & $16.14 \pm 1.73$ & NS \\
\hline & CG & $16.14 \pm 1.82$ & $16.14 \pm 1.82$ & $16.14 \pm 1.82$ & $16.14 \pm 1.82$ & \\
\hline & $P$ & NS & NS & NS & NS & \\
\hline \multirow[t]{3}{*}{ Final BW, kg } & $30.79 \pm 1.58$ & $31.36 \pm 1.60$ & $29.50 \pm 1.94$ & $29.36 \pm 3.02$ & $29.07 \pm 2.67$ & NS \\
\hline & CG & $30.79 \pm 1.58$ & $30.79 \pm 1.58$ & $30.79 \pm 1.58$ & $30.79 \pm 1.58$ & \\
\hline & $P$ & NS & NS & NS & NS & \\
\hline \multirow[t]{3}{*}{$\mathrm{ADG}, \mathrm{g} \mathrm{d}^{-1}$} & $122.02 \pm 10.95$ & $126.19 \pm 8.91$ & $110.12 \pm 13.79$ & $109.52 \pm 14.38$ & $107.74 \pm 23.38$ & * \\
\hline & CG & $122.02 \pm 10.95$ & $122.02 \pm 10.95$ & $122.02 \pm 10.95$ & $122.02 \pm 10.95$ & \\
\hline & $P$ & NS & $*$ & $*$ & NS & \\
\hline \multirow[t]{3}{*}{ FCR, $\%$} & $6.29 \pm 1.77$ & $6.10 \pm 1.24$ & $6.66 \pm 1.51$ & $6.34 \pm 1.11$ & $6.15 \pm 0.66$ & NS \\
\hline & $\mathrm{CG}$ & $6.29 \pm 1.77$ & $6.29 \pm 1.77$ & $6.29 \pm 1.77$ & $6.29 \pm 1.77$ & \\
\hline & $P$ & NS & NS & NS & NS & \\
\hline
\end{tabular}

${ }^{1} \mathrm{CG}$ : control group; VG: vitamin E treatment group.

${ }^{2} \mathrm{NS}$ : non significant; ${ }^{*} P<0.1 ; * * P<0.05 ; * * * P<0.01$.

${ }^{3} \mathrm{DMI}$ : DM intake; BW: body weight; ADG: average daily gain; FCR: feed conversion ratio. 
of the immune system of young animals (Kolb and Seehawer, 1998) and the recommended minimal requirement of vit $\mathrm{E}$ is lying between 10 and $15 \mathrm{mg} \mathrm{kg}^{-1}$ dietary DM by the Agricultural Research Council (ARC, 1980) for normal growth and health of sheep. Gentry et al. (1992) suggested that lambs receiving high levels of vit $\mathrm{E}$ supplementation may have a better growth performance. However, the results of the present study indicate that vit E supplementation to the diet of lambs had no significant effect on most growth performance traits, which is supported by the findings of Dufrasne et al. (2000), Macit et al. (2003a), and Maiorano et al. (2007). Differences in vit E effects on lamb growth performance may be ascribed to the factor of studying a different section of animal growth period length. Birch et al. (1994) showed that the beneficial effect of added vit $\mathrm{E}$ on growth performance is generally observed in very young animals.

\section{Carcass characteristics}

Measurements taken on hot carcasses are summarized in Table 3. Vitamin E supplementation did not have a significant effect on carcass traits in terms of hot carcass weight, LD muscle area (rib-eye area) and $\mathrm{pH} 45 \mathrm{~min}$ of LD muscle in 'Tan' sheep. However, there were significant differences among groups in most carcass characteristics, such as dressing percentage, total lean, subcutaneous fat, fat depth, drip loss and $\mathrm{pH} 24 \mathrm{~h}$.
Vitamin E supplementation levels below $100 \mathrm{IU} \mathrm{d}^{-1}$ lamb $^{-1}$ significantly increased dressing percentage and total lean, and those above $200 \mathrm{IU} \mathrm{d}^{-1}$ lamb $^{-1}$ significantly decreased subcutaneous fat and fat depth of Tan sheep lambs $(P<$ $0.01)$. In addition, vit $\mathrm{E}$ supplementation levels above 100 $\mathrm{IU} \mathrm{d} \mathrm{d}^{-1}$ lamb $^{-1}$ considerably reduced drip loss and $\mathrm{pH} 24$ $\mathrm{h}$ of LD muscles in 'Tan' sheep lambs $(P<0.01)$. The mean $\mathrm{pH}$ values of LD muscles consistently decreased from slaughter time up to $24 \mathrm{~h}$ postmortem for lambs in all treatment groups.

In this study, no significant differences among groups were observed for the main carcass indices, such as hot carcass weight, LD muscle area (rib-eye area) and $\mathrm{pH} 45$ min of LD muscles. These results of the present study are consistent with findings of Turner et al. (2002), Macit et al. (2003a), and Maiorano et al. (2007). However, the result of the current study that a moderate level $\left(200 \mathrm{IU} \mathrm{d}^{-1} \mathrm{lamb}^{-1}\right)$ of vit $\mathrm{E}$ supplementation had a suppressing effect on subcutaneous fat deposition in 'Tan' sheep was not reported in other studies involving in different breed of sheep (Turner et al., 2002; Macit et al., 2003b; Maiorano et al., 2007). But our result could be supported by the findings of Birch et al. (1994), who suggested that the suppressing effect of vit E supplementation on fat deposition might be due to vit E stimulation of the immune system, which caused a partitioning of energy away from growth and inhibited lipid catabolism. This hypothesis could be further demonstrated by the result reported above

Table 3. Effect of vitamin $E$ supplementation on carcass characteristics of 'Tan' sheep lambs.

\begin{tabular}{|c|c|c|c|c|c|c|}
\hline \multirow[b]{2}{*}{ Carcass traits } & \multicolumn{6}{|c|}{ Dietary vitamin E added levels $\left(\mathrm{IU} \mathrm{d}^{-1} \text { lamb }^{-1}\right)^{1}$} \\
\hline & $0(\mathrm{CG})$ & 20 (VG20) & $100($ VG100) & $200(\mathrm{VG} 200)$ & $2000(\mathrm{VG} 2000)$ & $p^{2}$ \\
\hline \multirow[t]{3}{*}{ Hot carcass, $\mathrm{kg}$} & $14.14 \pm 0.77$ & $14.89 \pm 0.98$ & $14.24 \pm 1.16$ & $13.43 \pm 1.51$ & $13.78 \pm 1.38$ & NS \\
\hline & CG & $14.14 \pm 0.77$ & $14.14 \pm 0.77$ & $14.14 \pm 0.77$ & $14.14 \pm 0.77$ & \\
\hline & $P$ & NS & NS & NS & NS & \\
\hline \multirow[t]{3}{*}{ Dressing proportion, $\%$} & $45.93 \pm 1.62$ & $47.45 \pm 2.28$ & $48.28 \pm 2.23 \mathrm{~A}$ & $45.71 \pm 1.78$ & $47.36 \pm 0.91$ & NS \\
\hline & CG & $45.93 \pm 1.62$ & $45.93 \pm 1.62 \mathrm{~B}$ & $45.93 \pm 1.62$ & $45.93 \pm 1.62$ & \\
\hline & $P$ & NS & $* *$ & NS & $*$ & \\
\hline \multirow[t]{3}{*}{ Total lean, kg } & $5.76 \pm 0.22$ & $6.34 \pm 0.35 \mathrm{~A}$ & $6.72 \pm 0.88 \mathrm{~A}$ & $6.23 \pm 0.53$ & $6.18 \pm 0.61$ & NS \\
\hline & CG & $5.76 \pm 0.22 \mathrm{~B}$ & $5.76 \pm 0.22 \mathrm{~B}$ & $5.76 \pm 0.22$ & $5.76 \pm 0.22$ & \\
\hline & $P$ & $* * *$ & ** & NS & NS & \\
\hline \multirow[t]{3}{*}{ Subcutaneous fat, $\mathrm{kg}$} & $2.40 \pm 0.39 \mathrm{a}$ & $2.14 \pm 0.52 \mathrm{a}$ & $2.06 \pm 0.13 \mathrm{a}$ & $1.50 \pm 0.19 \mathrm{bB}$ & $1.49 \pm 0.20 \mathrm{bB}$ & $* * *$ \\
\hline & $\mathrm{CG}$ & $2.40 \pm 0.39$ & $2.40 \pm 0.39$ & $2.40 \pm 0.39 \mathrm{~A}$ & $2.40 \pm 0.39 \mathrm{~A}$ & \\
\hline & $P$ & NS & $*$ & $* * *$ & $* * *$ & \\
\hline \multirow[t]{3}{*}{ Fat depth, mm } & $1.86 \pm 0.021 \mathrm{a}$ & $1.85 \pm 0.029 \mathrm{ab}$ & $1.83 \pm 0.038 \mathrm{ab}$ & $1.83 \pm 0.032 \mathrm{bB}$ & $1.76 \pm 0.027 \mathrm{cB}$ & $* * *$ \\
\hline & $\mathrm{CG}$ & $1.86 \pm 0.021$ & $1.86 \pm 0.021$ & $1.86 \pm 0.021 \mathrm{~A}$ & $1.86 \pm 0.021 \mathrm{~A}$ & \\
\hline & $P$ & NS & $*$ & $* *$ & $* * *$ & \\
\hline \multirow[t]{3}{*}{ Rib-eye area, $\mathrm{cm}^{2}$} & $13.69 \pm 1.47$ & $13.31 \pm 1.06$ & $13.17 \pm 2.38$ & $13.03 \pm 1.30$ & $12.83 \pm 1.53$ & NS \\
\hline & $\mathrm{CG}$ & $13.69 \pm 1.47$ & $13.69 \pm 1.47$ & $13.69 \pm 1.47$ & $13.69 \pm 1.47$ & \\
\hline & $P$ & NS & NS & NS & NS & \\
\hline \multirow[t]{3}{*}{ Drip loss, $\%$} & $1.50 \pm 0.33 \mathrm{ab}$ & $1.62 \pm 0.26 a$ & $1.33 \pm 0.27 \mathrm{cb}$ & $1.22 \pm 0.19 \mathrm{cb}$ & $1.12 \pm 0.14 \mathrm{cB}$ & $* * *$ \\
\hline & $\mathrm{CG}$ & $1.50 \pm 0.33$ & $1.50 \pm 0.33$ & $1.50 \pm 0.33$ & $1.50 \pm 0.33 \mathrm{~A}$ & \\
\hline & $P$ & NS & NS & * & $* *$ & \\
\hline \multirow[t]{3}{*}{$\mathrm{pH} 45 \mathrm{~min}$} & $6.21 \pm 0.22$ & $6.38 \pm 0.17$ & $6.42 \pm 0.19$ & $6.42 \pm 0.23$ & $6.14 \pm 0.26$ & NS \\
\hline & $\mathrm{CG}$ & $6.21 \pm 0.22$ & $6.21 \pm 0.22$ & $6.21 \pm 0.22$ & $6.21 \pm 0.22$ & \\
\hline & $P$ & NS & $*$ & NS & NS & \\
\hline \multirow[t]{3}{*}{$\mathrm{pH} 24 \mathrm{~h}$} & $5.85 \pm 0.10 \mathrm{a}$ & $5.77 \pm 0.27 \mathrm{ab}$ & $5.51 \pm 0.14 \mathrm{cB}$ & $5.65 \pm 0.13 \mathrm{abcB}$ & $5.56 \pm 0.23 \mathrm{bcB}$ & $* * *$ \\
\hline & $\mathrm{CG}$ & $5.85 \pm 0.10$ & $5.85 \pm 0.10 \mathrm{~A}$ & $5.85 \pm 0.10 \mathrm{~A}$ & $5.85 \pm 0.10 \mathrm{~A}$ & \\
\hline & $P$ & NS & $* * *$ & $* * *$ & $* * *$ & \\
\hline
\end{tabular}

${ }^{2} \mathrm{CG}$ : control group; VG: vit E treatment group.

${ }^{2} \mathrm{NS}$ : non significant; $* P<0.1 ; * * P<0.05 ; * * * P<0.01$.

${ }^{\mathrm{a}, \mathrm{b}, \mathrm{c}}$ Means within the same row with different letters differ significantly according to Duncan's multiple range tests $(P<0.05)$.

${ }^{\mathrm{A}, \mathrm{B}}$ Means within the same column with different letters differ significantly according to $t$ test $(P<0.05)$. 
that vit E supplementation tended to reduce ADG of 'Tan' sheep lambs.

It was unexpected that VG lambs supplemented with $100 \mathrm{IU}$ vit $\mathrm{E} \mathrm{d}^{-1}$ lamb $^{-1}$ showed better performance than CG lambs in terms of dressing percentage and total lean in the present study. This result was not reported in most previous studies with different breed of sheep (Turner et al., 2002; Macit et al., 2003b; Maiorano et al., 2007). This result indicates that the normal requirement of vit $\mathrm{E}$ for growth of 'Tan' sheep lambs may be higher than that of other sheep genotypes. Besides, it was found that drip loss was significantly suppressed by moderate and high levels of vit E supplementation, which was also observed by Morrisey et al. (1994), Mitsumoto et al. (1998), Dufrasne et al. (2000), and Macit et al. (2003a). These results indicate that vit $\mathrm{E}$ can suppress drip loss of mutton within a short storage period.

It is well known that the ultimate $\mathrm{pH}$ of the muscle is an important contributing factor to meat quality (Maiorano et al., 2007). Higher Longissimus muscle $\mathrm{pH}$ values at 24 $\mathrm{h}$ postmortem produced poor quality meat (Chrystall and Daly, 1996). In this study, although vit E treatment had no effect on $\mathrm{pH} 45 \mathrm{~min}(P>0.05)$, moderate and high levels of vit E supplementation clearly reduce $\mathrm{pH} 24 \mathrm{~h}$ of LD muscles $(P<0.001)$. Cheah et al. (1995) and Castellini et al. (1999) observed that the ability of vit $E$ to stabilize membranes is presumably achieved by decreasing $\mathrm{Ca}^{2+}$ release which reduces phospholipase $\mathrm{A}_{2}$ activity and, hence, phospholipid hydrolysis. Decreased levels of cytosolic $\mathrm{Ca}^{2+}$ reduce the rate of postmortem glycolysis resulting in a higher postmortem $\mathrm{pH}$.

\section{Lipid content and intramuscular fatty acid composition of LD muscle}

The results of content and fatty acid composition of intramuscular lipids in LD muscle are presented in Table 4. The vit E treatments did not significantly affect the contents of both intramuscular lipids and total fatty acids (TFA) in LD muscle, except for a lower $(P<0.01)$ content of TFA in LD muscle of the VG lambs with $2000 \mathrm{IU} \mathrm{d}^{-1}$ lamb $^{-1} \alpha$-tocopheryl acetate compared to that of $\mathrm{CG}$. These data are in agreement with the findings of Salvatori et al. (2004) and Kasapidou et al. (2012).

Within diets, there were some significant effects of the level of vit E supplementation on fatty acid composition of intramuscular lipids in LD muscle. The moderate levels (100 and $200 \mathrm{IU} \mathrm{d}^{-1}$ lamb $^{-1}$ ) of vit $\mathrm{E}$ supplementation considerably $(P<0.01)$ increased the proportions of C8:0, C12:0, C14:0 and C15:0 fatty acids. The lambs from vit $\mathrm{E}$ treatment groups with 200 and $2000 \mathrm{IU} \mathrm{d}^{-1}$ lamb $^{-1}$ $\alpha$-tocopheryl acetate had higher $(P<0.05)$ percentages of C16:1, C18:2, C18:3 and C20:3 than those in CG, whereas these levels of vit E supplementation significantly $(P<$ 0.01 ) reduced the proportion of C18:1 in intramuscular lipids of LD muscle. In general, with regard to SFA, although slightly higher proportions of C8:0, C12:0, C14:0, and C15:0 were observed for VG lambs compared to those in $\mathrm{CG}$, the general SFA proportion was not modified by vit E supplementation. Similar results were obtained by Kasapidou et al. (2012) on 'Suffolk' × 'Charollais' wether lambs, who detected no effect of vit $\mathrm{E}$ on fatty acid composition of neutral lipids, which are mainly consisted of SFA, in intramuscular lipids of semimembranosus muscle. As for MUFA, proportions of C14:1 and C16:1 were significantly increased by vit $\mathrm{E}$ supplementation with an inversely effect on $\mathrm{C} 18: 1$ percentage $(P<0.05)$, which finally resulted in a decreasing tendency for MUFA proportion of LD muscle in VG lambs $(P<0.1)$. This result could be supported by the findings of Hou et al. (2012), who reported that vit E supplementation could accelerate the ruminal biohydrogenation of C18:1 unsaturated fatty acids in vitro. For PUFA, the results showed that the proportion of linoleic acid (C18:2n6) was significantly increased $(P<0.05)$ and a similar trend $(P$ $<0.1)$ was also observed for C20:3n6 percentage of LD muscle resulting in a significant increase $(P<0.05)$ in n-6 PUFA proportion and in ratio of n-6 PUFA/n-3 PUFA, but with no significant effect on total PUFA proportion in LD muscle. These results were similar with our previous study on Boer male kids and were also supported by the findings of Salvatori et al. (2004) and Kasapidou et al. (2012). In addition, an increasing tendency $(P<0.1)$ for both PUFA proportion and the ratio of PUFA/SFA in LD muscle of lambs treated with vit $\mathrm{E}$ was also detected in the present study. According to these results from the present study, vit E levels did influence some aspects of fatty acid profiles of LD muscle lipids, especially for phospholipid fraction, in 'Tan' sheep lambs, which demonstrated that vit E supplementation may have some beneficial effect on meat quality as protecting intramuscular lipids against oxidation in live sheep. The mechanism for vit E supplementation affecting fatty acid profiles of intramuscular fat may be related with the findings that vit $\mathrm{E}$ could modify ruminal pathways of PUFA biohydrogenation in dairy (Pottier et al., 2006; Bell et al., 2006), beef cattle (Juárez et al., 2010; Juárez et al., 2011), and goat (Hou et al., 2012), acting either as an inhibitor of bacteria producing trans-10 C18:1 or as an electron acceptor for Butyrivibrio fibrisolvens (Pottier et al., 2006).

\section{CONCLUSIONS}

In conclusion, vitamin $\mathrm{E}$ supplementation to the diet of 'Tan' sheep lambs at a wide range of inclusion rate from 20 to $2000 \mathrm{IU} \mathrm{d}^{-1}$ lamb $^{-1}$ showed no differences in growth performance, and relatively affected carcass characteristics with the addition levels over $200 \mathrm{IU} \mathrm{d}^{-1}$ lamb $^{-1}$ as significantly decreasing subcutaneous fat deposition, drip loss, and $\mathrm{pH} 24 \mathrm{~h}$. As for fatty acid composition of intramuscular lipids, vit E supplementation could significantly increase n-6 PUFA proportion and the ratio of n-6/n-3 PUFA and tended to enhance PUFA proportion and the ratio of PUFA/ 
Table 4. Effect of vitamin E supplementation on content and fatty acid composition of intramuscular lipid in Longissimus dorsi muscle of 'Tan' sheep lambs.

\begin{tabular}{|c|c|c|c|c|c|c|}
\hline \multirow[b]{2}{*}{ Fatty $\operatorname{acid}^{3}(\%)$} & \multicolumn{6}{|c|}{ Dietary vitamin $\mathrm{E}$ added levels $\left(\mathrm{IU} \mathrm{d}^{-1} \mathrm{lamb}^{-1}\right)^{1}$} \\
\hline & $0(\mathrm{CG})$ & $20(\mathrm{VG} 20)$ & $100(\mathrm{VG} 100)$ & $200($ VG200) & $2000(\mathrm{VG} 2000)$ & $p^{2}$ \\
\hline \multirow{3}{*}{ IMF, g $100 \mathrm{~g}^{-1} \mathrm{DM}$} & $12.48 \pm 3.32$ & $13.26 \pm 2.42$ & $12.43 \pm 1.87$ & $11.31 \pm 1.31$ & $11.60 \pm 3.44$ & NS \\
\hline & CG & $12.48 \pm 3.32$ & $12.48 \pm 3.32$ & $12.48 \pm 3.32$ & $12.48 \pm 3.32$ & \\
\hline & $P$ & NS & NS & NS & NS & \\
\hline \multirow[t]{3}{*}{ TFA, $\mathrm{mg} \mathrm{g}^{-1}$} & $110.78 \pm 17.37$ & $114.83 \pm 23.14$ & $103.55 \pm 23.08$ & $90.19 \pm 34.17$ & $79.62 \pm 17.83 \mathrm{~B}$ & NS \\
\hline & CG & $110.78 \pm 17.37$ & $110.78 \pm 17.37$ & $110.78 \pm 17.37$ & $110.78 \pm 17.37 \mathrm{~A}$ & \\
\hline & $P$ & NS & NS & NS & $* * *$ & \\
\hline \multirow[t]{3}{*}{$\mathrm{C} 8: 0$} & $0.022 \pm 0.0024 b$ & $0.022 \pm 0.0015 b$ & $0.025 \pm 0.0058 \mathrm{ab}$ & $0.029 \pm 0.0046 \mathrm{aA}$ & - & $* *$ \\
\hline & $\mathrm{CG}$ & $0.022 \pm 0.0024$ & $0.022 \pm 0.0024$ & $0.022 \pm 0.0024 \mathrm{~B}$ & & \\
\hline & $P$ & NS & NS & $* * *$ & & \\
\hline \multirow[t]{3}{*}{ C10:0 } & $0.056 \pm 0.072$ & $0.084 \pm 0.093$ & $0.069 \pm 0.089$ & $0.092 \pm 0.095$ & $0.13 \pm 0.10$ & NS \\
\hline & CG & $0.056 \pm 0.072$ & $0.056 \pm 0.072$ & $0.056 \pm 0.072$ & $0.056 \pm 0.072$ & \\
\hline & $P$ & NS & NS & NS & NS & \\
\hline \multirow[t]{3}{*}{$\mathrm{C} 12: 0$} & $0.094 \pm 0.019 b$ & $0.15 \pm 0.034 \mathrm{aA}$ & $0.13 \pm 0.045 \mathrm{ab}$ & $0.12 \pm 0.041 \mathrm{ab}$ & $0.13 \pm 0.028 \mathrm{abA}$ & NS \\
\hline & $\mathrm{CG}$ & $0.094 \pm 0.019 \mathrm{~B}$ & $0.094 \pm 0.019$ & $0.094 \pm 0.019$ & $0.094 \pm 0.019 \mathrm{~B}$ & \\
\hline & $P$ & $* * *$ & $*$ & NS & $* * *$ & \\
\hline \multirow[t]{3}{*}{ C13:0 } & $0.017 \pm 0.0017$ & $0.012 \pm 0.0031$ & $0.014 \pm 0.0085$ & $0.013 \pm 0.0028$ & $0.016 \pm 0.0024$ & NS \\
\hline & CG & $0.017 \pm 0.0017$ & $0.017 \pm 0.0017$ & $0.017 \pm 0.0017$ & $0.017 \pm 0.0017$ & \\
\hline & $P$ & NS & NS & NS & NS & \\
\hline \multirow[t]{3}{*}{ C14:0 } & $1.84 \pm 0.26 b$ & $2.32 \pm 0.39 \mathrm{aA}$ & $2.28 \pm 0.36 \mathrm{aA}$ & $1.81 \pm 0.34 b$ & $2.13 \pm 0.40 \mathrm{ab}$ & $* *$ \\
\hline & CG & $1.84 \pm 0.26 \mathrm{~B}$ & $1.84 \pm 0.26 \mathrm{~B}$ & $1.84 \pm 0.26$ & $1.84 \pm 0.26$ & \\
\hline & $P$ & $* *$ & $* *$ & NS & NS & \\
\hline \multirow[t]{3}{*}{$\mathrm{C} 14: 1 n 7$} & $0.065 \pm 0.014 b$ & $0.081 \pm 0.014 \mathrm{ab}$ & $0.093 \pm 0.027 \mathrm{aA}$ & $0.066 \pm 0.012 b$ & $0.078 \pm 0.014 \mathrm{ab}$ & $* *$ \\
\hline & $\mathrm{CG}$ & $0.065 \pm 0.014$ & $0.065 \pm 0.014 \mathrm{~B}$ & $0.065 \pm 0.014$ & $0.065 \pm 0.014$ & \\
\hline & $P$ & $*$ & $* *$ & NS & NS & \\
\hline \multirow[t]{3}{*}{ C15:0 } & $0.23 \pm 0.020 \mathrm{~b}$ & $0.31 \pm 0.037 \mathrm{aA}$ & $0.28 \pm 0.054 \mathrm{ab}$ & $0.30 \pm 0.045 \mathrm{abA}$ & $0.31 \pm 0.092 \mathrm{a}$ & NS \\
\hline & CG & $0.23 \pm 0.020 \mathrm{~B}$ & $0.23 \pm 0.020$ & $0.23 \pm 0.020 \mathrm{~B}$ & $0.23 \pm 0.020$ & \\
\hline & $P$ & $* * *$ & $*$ & *** & $*$ & \\
\hline \multirow[t]{3}{*}{ C16:0 } & $24.24 \pm 0.97$ & $24.98 \pm 1.40$ & $25.03 \pm 1.56$ & $23.67 \pm 1.31$ & $23.84 \pm 1.40$ & NS \\
\hline & $\mathrm{CG}$ & $24.24 \pm 0.97$ & $24.24 \pm 0.97$ & $24.24 \pm 0.97$ & $24.24 \pm 0.97$ & \\
\hline & $P$ & NS & NS & NS & NS & \\
\hline $\mathrm{C} 16: \ln 7$ & $1.39 \pm 0.17 b$ & $1.51 \pm 0.15 \mathrm{ab}$ & $1.66 \pm 0.17 \mathrm{aA}$ & $1.52 \pm 0.18 \mathrm{ab}$ & $1.59 \pm 0.13 \mathrm{aA}$ & $* *$ \\
\hline & $\mathrm{CG}$ & $1.39 \pm 0.17$ & $1.39 \pm 0.17 \mathrm{~B}$ & $1.39 \pm 0.17$ & $1.39 \pm 0.17 \mathrm{~B}$ & \\
\hline & $P$ & NS & ** & NS & ** & \\
\hline C17:0 & $0.83 \pm 0.35$ & $1.03 \pm 0.057$ & $0.96 \pm 0.061$ & $0.78 \pm 0.50$ & $0.79 \pm 0.52$ & NS \\
\hline & CG & $0.83 \pm 0.35$ & $0.83 \pm 0.35$ & $0.83 \pm 0.35$ & $0.83 \pm 0.35$ & \\
\hline & $P$ & NS & NS & NS & NS & \\
\hline C18:0 & $20.73 \pm 0.88$ & $20.01 \pm 1.71$ & $19.37 \pm 1.56$ & $20.44 \pm 1.18$ & $20.74 \pm 2.33$ & NS \\
\hline & CG & $20.73 \pm 0.88$ & $20.73 \pm 0.88$ & $20.73 \pm 0.88$ & $20.73 \pm 0.88$ & \\
\hline & $P$ & NS & $*$ & NS & NS & \\
\hline $\mathrm{C} 18: 1 n 11 \mathrm{t}$ & $0.44 \pm 0.039$ & $0.42 \pm 0.13$ & $0.44 \pm 0.067$ & $0.42 \pm 0.039$ & $0.40 \pm 0.059$ & NS \\
\hline & CG & $0.44 \pm 0.039$ & $0.44 \pm 0.039$ & $0.44 \pm 0.039$ & $0.44 \pm 0.039$ & \\
\hline & $P$ & NS & NS & NS & NS & \\
\hline $\mathrm{C} 18: 1 n 9 \mathrm{c}$ & $42.55 \pm 1.31 \mathrm{a}$ & $41.53 \pm 0.82 \mathrm{ab}$ & $41.74 \pm 1.49 \mathrm{ab}$ & $40.67 \pm 1.33 \mathrm{bcB}$ & $39.84 \pm 1.75 \mathrm{cB}$ & $* *$ \\
\hline & $\mathrm{CG}$ & $42.55 \pm 1.31$ & $42.55 \pm 1.31$ & $42.55 \pm 1.31 \mathrm{~A}$ & $42.55 \pm 1.31 \mathrm{~A}$ & \\
\hline & $P$ & NS & NS & $* *$ & *** & \\
\hline $\mathrm{C} 18: 2 n 6 \mathrm{t}$ & $0.078 \pm 0.015 b$ & $0.071 \pm 0.0078 \mathrm{~b}$ & $0.085 \pm 0.012 b$ & $0.18 \pm 0.18 \mathrm{ab}$ & $0.26 \pm 0.18 \mathrm{aA}$ & $* *$ \\
\hline & $\mathrm{CG}$ & $0.078 \pm 0.015$ & $0.078 \pm 0.015$ & $0.078 \pm 0.015$ & $0.078 \pm 0.015 B$ & \\
\hline & $P$ & NS & NS & NS & $* *$ & \\
\hline $\mathrm{C} 18: 2 n 6 \mathrm{c}$ & $3.57 \pm 0.73 c$ & $3.81 \pm 0.56 b c$ & $3.73 \pm 0.78 c$ & $5.07 \pm 1.42 \mathrm{aA}$ & $4.96 \pm 1.24 \mathrm{abA}$ & $* *$ \\
\hline & $\mathrm{CG}$ & $3.57 \pm 0.73$ & $3.57 \pm 0.73$ & $3.57 \pm 0.73 \mathrm{~B}$ & $3.57 \pm 0.73 \mathrm{~B}$ & \\
\hline & $P$ & NS & NS & $* *$ & $* *$ & \\
\hline $\mathrm{C} 18: 3 n 6$ & $0.17 \pm 0.032$ & $0.17 \pm 0.018$ & $0.15 \pm 0.018$ & $0.19 \pm 0.020$ & $0.18 \pm 0.027$ & NS \\
\hline & $\mathrm{CG}$ & $0.17 \pm 0.032$ & $0.17 \pm 0.032$ & $0.17 \pm 0.032$ & $0.17 \pm 0.032$ & \\
\hline & $P$ & NS & NS & NS & NS & \\
\hline $\mathrm{C} 18: 3 n 3$ & $0.21 \pm 0.057$ & $0.26 \pm 0.052$ & $0.24 \pm 0.083$ & $0.29 \pm 0.052 \mathrm{~A}$ & $0.29 \pm 0.075 \mathrm{~A}$ & NS \\
\hline & $\mathrm{CG}$ & $0.21 \pm 0.057$ & $0.21 \pm 0.057$ & $0.21 \pm 0.057 \mathrm{~B}$ & $0.21 \pm 0.057 \mathrm{~B}$ & \\
\hline & $P$ & NS & NS & ** & ** & \\
\hline CLA-c9t11 & $0.18 \pm 0.034$ & $0.19 \pm 0.022$ & $0.19 \pm 0.050$ & $0.17 \pm 0.039$ & $0.16 \pm 0.031$ & NS \\
\hline & CG & $0.18 \pm 0.034$ & $0.18 \pm 0.034$ & $0.18 \pm 0.034$ & $0.18 \pm 0.034$ & \\
\hline & $P$ & NS & NS & NS & NS & \\
\hline CLA-t10c12 & $0.026 \pm 0.017$ & $0.034 \pm 0.013$ & $0.043 \pm 0.025$ & $0.032 \pm 0.012$ & $0.048 \pm 0.021$ & NS \\
\hline & CG & $0.026 \pm 0.017$ & $0.026 \pm 0.017$ & $0.026 \pm 0.017$ & $0.026 \pm 0.017$ & \\
\hline & $P$ & NS & NS & NS & $*$ & \\
\hline C20:0 & $0.14 \pm 0.045$ & $0.16 \pm 0.033$ & $0.14 \pm 0.025$ & $0.16 \pm 0.026$ & $0.16 \pm 0.016$ & NS \\
\hline & CG & $0.14 \pm 0.045$ & $0.14 \pm 0.045$ & $0.14 \pm 0.045$ & $0.14 \pm 0.045$ & \\
\hline & $P$ & NS & NS & NS & * & \\
\hline
\end{tabular}




\begin{tabular}{|c|c|c|c|c|c|c|}
\hline \multirow[b]{2}{*}{ Fatty $\operatorname{acid}^{3}(\%)$} & \multicolumn{6}{|c|}{ Dietary vitamin $\mathrm{E}$ added levels $\left(\mathrm{IU} \mathrm{d}^{-1} \mathrm{lamb}^{-1}\right)^{1}$} \\
\hline & $0(\mathrm{CG})$ & $20(\mathrm{VG} 20)$ & $100(\mathrm{VG} 100)$ & $200(\mathrm{VG} 200)$ & $2000(\mathrm{VG} 2000)$ & $p^{2}$ \\
\hline \multirow[t]{3}{*}{$\mathrm{C} 20: \ln 9$} & $0.094 \pm 0.0062$ & $0.089 \pm 0.012$ & $0.10 \pm 0.023$ & $0.098 \pm 0.020$ & $0.094 \pm 0.013$ & NS \\
\hline & $\mathrm{CG}$ & $0.094 \pm 0.0062$ & $0.094 \pm 0.0062$ & $0.094 \pm 0.0062$ & $0.094 \pm 0.0062$ & \\
\hline & $P$ & NS & NS & NS & NS & \\
\hline \multirow[t]{3}{*}{$\mathrm{C} 21: 0$} & $0.49 \pm 0.086$ & $0.43 \pm 0.089$ & $0.49 \pm 0.13$ & $0.63 \pm 0.18$ & $0.62 \pm 0.18$ & $*$ \\
\hline & $\mathrm{CG}$ & $0.49 \pm 0.086$ & $0.49 \pm 0.086$ & $0.49 \pm 0.086$ & $0.49 \pm 0.086$ & \\
\hline & $P$ & NS & NS & $*$ & NS & \\
\hline \multirow[t]{3}{*}{$\mathrm{C} 20: 3 n 6$} & $0.17 \pm 0.035$ & $0.17 \pm 0.033$ & $0.18 \pm 0.036$ & $0.23 \pm 0.089$ & $0.23 \pm 0.065 \mathrm{~A}$ & $*$ \\
\hline & $\mathrm{CG}$ & $0.17 \pm 0.035$ & $0.17 \pm 0.035$ & $0.17 \pm 0.035$ & $0.17 \pm 0.035 \mathrm{~B}$ & \\
\hline & $P$ & NS & NS & * & $* *$ & \\
\hline \multirow[t]{3}{*}{$\mathrm{C} 20: 4 n 6$} & $1.96 \pm 0.58$ & $1.83 \pm 0.32$ & $2.17 \pm 0.51$ & $2.59 \pm 0.89$ & $2.64 \pm 0.88$ & NS \\
\hline & CG & $1.96 \pm 0.58$ & $1.96 \pm 0.58$ & $1.96 \pm 0.58$ & $1.96 \pm 0.58$ & \\
\hline & $P$ & NS & NS & NS & NS & \\
\hline \multirow[t]{3}{*}{$\mathrm{C} 20: 5 n 3$} & $0.11 \pm 0.058$ & $0.11 \pm 0.043$ & $0.12 \pm 0.039$ & $0.13 \pm 0.064$ & $0.16 \pm 0.081$ & NS \\
\hline & $\mathrm{CG}$ & $0.11 \pm 0.058$ & $0.11 \pm 0.058$ & $0.11 \pm 0.058$ & $0.11 \pm 0.058$ & \\
\hline & $P$ & NS & NS & NS & NS & \\
\hline \multirow[t]{3}{*}{$\mathrm{C} 22: 0$} & $0.089 \pm 0.010$ & $0.12 \pm 0.024 \mathrm{~A}$ & $0.093 \pm 0.013$ & $0.12 \pm 0.044$ & $0.10 \pm 0.025$ & NS \\
\hline & $\mathrm{CG}$ & $0.089 \pm 0.010 \mathrm{~B}$ & $0.089 \pm 0.010$ & $0.089 \pm 0.010$ & $0.089 \pm 0.010$ & \\
\hline & $P$ & $* *$ & NS & $*$ & NS & \\
\hline \multirow[t]{3}{*}{$\mathrm{C} 22: 6 n 3$} & $0.22 \pm 0.10$ & $0.17 \pm 0.12$ & $0.21 \pm 0.040$ & $0.24 \pm 0.094$ & $0.26 \pm 0.10$ & NS \\
\hline & CG & $0.22 \pm 0.10$ & $0.22 \pm 0.10$ & $0.22 \pm 0.10$ & $0.22 \pm 0.10$ & \\
\hline & $P$ & NS & NS & NS & NS & \\
\hline \multirow[t]{3}{*}{$\mathrm{C} \leq 10$} & $0.078 \pm 0.073$ & $0.11 \pm 0.093$ & $0.094 \pm 0.088$ & $0.12 \pm 0.099$ & $0.13 \pm 0.10$ & NS \\
\hline & $\mathrm{CG}$ & $0.078 \pm 0.073$ & $0.078 \pm 0.073$ & $0.078 \pm 0.073$ & $0.078 \pm 0.073$ & \\
\hline & $P$ & NS & NS & NS & NS & \\
\hline \multirow[t]{3}{*}{$\sum n-6$ PUFA } & $5.96 \pm 1.32 b$ & $6.05 \pm 0.92 b$ & $6.31 \pm 1.29 \mathrm{ab}$ & $8.26 \pm 2.45 \mathrm{aA}$ & $8.28 \pm 2.23 \mathrm{aA}$ & $* *$ \\
\hline & CG & $5.96 \pm 1.32$ & $5.96 \pm 1.32$ & $5.96 \pm 1.32 \mathrm{~B}$ & $5.96 \pm 1.32 \mathrm{~B}$ & \\
\hline & $P$ & NS & NS & $* *$ & ** & \\
\hline \multirow[t]{3}{*}{$\sum n-3$ PUFA } & $0.54 \pm 0.21$ & $0.54 \pm 0.20$ & $0.58 \pm 0.15$ & $0.66 \pm 0.20$ & $0.64 \pm 0.29$ & NS \\
\hline & $\mathrm{CG}$ & $0.54 \pm 0.21$ & $0.54 \pm 0.21$ & $0.54 \pm 0.21$ & $0.54 \pm 0.21$ & \\
\hline & $P$ & NS & NS & NS & NS & \\
\hline \multirow[t]{3}{*}{$n-6 / n-3$} & $6.50 \pm 1.49 b$ & $6.59 \pm 1.11 b$ & $6.89 \pm 1.40 b$ & $8.92 \pm 2.64 a$ & $8.92 \pm 2.43 \mathrm{aA}$ & $* *$ \\
\hline & $\mathrm{CG}$ & $6.50 \pm 1.49$ & $6.50 \pm 1.49$ & $6.50 \pm 1.49$ & $6.50 \pm 1.49 \mathrm{~B}$ & \\
\hline & $P$ & NS & NS & $*$ & $* *$ & \\
\hline \multirow[t]{3}{*}{$\Sigma$ SFA } & $48.76 \pm 1.20$ & $49.55 \pm 1.50$ & $48.85 \pm 2.16$ & $48.11 \pm 2.22$ & $48.89 \pm 3.34$ & NS \\
\hline & $\mathrm{CG}$ & $48.76 \pm 1.20$ & $48.76 \pm 1.20$ & $48.76 \pm 1.20$ & $48.76 \pm 1.20$ & \\
\hline & $P$ & NS & NS & NS & NS & \\
\hline \multirow[t]{3}{*}{$\Sigma$ MUFA } & $44.53 \pm 1.22$ & $43.63 \pm 0.83$ & $44.03 \pm 1.57$ & $42.77 \pm 1.48 \mathrm{~B}$ & $41.99 \pm 1.85 \mathrm{~B}$ & $*$ \\
\hline & CG & $44.53 \pm 1.22$ & $44.53 \pm 1.22$ & $44.53 \pm 1.22 \mathrm{~A}$ & $44.53 \pm 1.22 \mathrm{~A}$ & \\
\hline & $P$ & NS & NS & $* *$ & $* *$ & \\
\hline \multirow[t]{3}{*}{$\sum$ PUFA } & $6.70 \pm 1.52$ & $6.81 \pm 1.10$ & $7.12 \pm 1.46$ & $9.12 \pm 2.63$ & $9.12 \pm 2.45 \mathrm{~A}$ & $*$ \\
\hline & $\mathrm{CG}$ & $6.71 \pm 1.52$ & $6.71 \pm 1.52$ & $6.71 \pm 1.52$ & $6.71 \pm 1.52 \mathrm{~B}$ & \\
\hline & $P$ & NS & NS & $*$ & $* *$ & \\
\hline \multirow[t]{3}{*}{ PUFA/SFA } & $0.14 \pm 0.033$ & $0.14 \pm 0.026$ & $0.15 \pm 0.035$ & $0.19 \pm 0.062$ & $0.19 \pm 0.063$ & $*$ \\
\hline & $\mathrm{CG}$ & $0.14 \pm 0.033$ & $0.14 \pm 0.033$ & $0.14 \pm 0.033$ & $0.14 \pm 0.033$ & \\
\hline & $P$ & NS & NS & $*$ & $*$ & \\
\hline
\end{tabular}

${ }^{1}$ CG: control group; VG: vit E treatment group; results are expressed as g $100 \mathrm{~g}^{-1}$ frozen-dry muscle for intramuscular lipid, as mg g ${ }^{-1}$ of muscle for total fatty acids (TFA) and as percentage of TFA for each fatty acid. Each value is expressed as mean \pm SD.

${ }^{2} \mathrm{NS}$ : non significant; $* P<0.1 ; * * P<0.05 ; * * * P<0.01$.

${ }^{3}$ IMF: Intramuscular fat; PUFA: polyunsaturated fatty acids; SFA: saturated fatty acids; MUFA: monounsaturated fatty acids.

a,b, Means within the same row with different letters differ significantly according to Duncan's multiple range tests $(P<0.05)$.

${ }^{\mathrm{A}, \mathrm{B}}$ Means within the same column with different letters differ significantly according to $\mathrm{t}$ test $(P<0.05)$.

SFA in Longissimus dorsi muscle of 'Tan' sheep. These results indicate that it is necessary to make a re-evaluation of the currently recommended levels of vit $\mathrm{E}$ in sheep diets to meet the requirements of consumers for more healthy meat consumption and that of dealers for modern retailing practices.

\section{ACKNOWLEDGEMENTS}

Thanks are due to Stan Bara of Northern Alberta Institute of Technology for comments and corrections on this manuscript. The present study was supported by the projects (200903060 and CARS-39) of China Agricultural Ministry.

\section{LITERATURE CITED}

Álvarez, I., J. De la Fuente, M.T. Díaz, S. Lauzerica, C. Pérez, and V. Cañeque. 2008. Estimation of $\alpha$-tocopherol concentration necessary to optimize lamb meat quality stability during frozen storage in high-oxygen modified using broken-line regression analysis. Animal 2:1405-1411. 
AOAC. 1990. Official methods of analysis. $15^{\text {th }}$ ed. Association of Official Analysis Chemists (AOAC), Washington, DC., USA.

ARC. 1980. The nutrient requirements of ruminant livestock. Commonwealth Agricultural Bureaux. Agricultural Research Council (ARC), Slough, UK.

Awawdeh, M.S., B.S. Obeidat, and R.T. Kridli. 2009. Yellow grease as an alternative energy source for nursing Awassi ewes and their suckling lambs. Animal Feed Science and Technology 152:165174.

Bell, J.A., J.M. Griinari, and J.J. Kennelly. 2006. Effect of safflower oil, flaxseed oil, monensin, and vitamin $\mathrm{E}$ on concentration of conjugated linoleic acid in bovine milk fat. Journal of Dairy Science 89:733-748.

Birch, K.S., J.D. Thomas, and T.T. Ross. 1994. Growth and carcass characteristics of newly received feeder lambs treated with probiotics and vitamin E. Sheep and Goat Research Journal 10:201-206.

Castellini, C., A. Dal Bosco, and M. Bernardini. 1999. Effect of dietary vitamin $\mathrm{E}$ supplementation on the characteristics of refrigerated and frozen rabbit meat. Italian Journal of Food Science 2:151-160

Cheah, K.S., A.M. Cheah, and D.I. Krausgrill. 1995. Effect of dietary supplementation of vitamin E on pig meat quality. Meat Science 39:255-264.

Chrystall, B.B., and C.C. Daly. 1996. Processing for meat quality. In Proceedings of the New Zealand Society of Animal Production, Hamilton, New Zealand.

Dufrasne, I., C. Marche, A. Clinquart, J.L. Hornick, C. Van Eenaeme, and L. Istasse. 2000. Effects of dietary vitamin E supplementation on performance and meat characteristics in fattening bulls from Belgian Blue breed. Livestock Production Science 65:197-201.

Duncan, D.B. 1955. Multiple range and multiple F tests. Biometrics 11:1-42.

Enser, M., K. Hallett, B. Hewitt, G.A.J. Fursey, and J.D. Wood. 1996. Fatty acid content and composition of English beef, lamb and pork at retail. Meat Science 42:443-456.

Evans, H.M., and K.S. Bishop. 1922. On the existence of a hitherto unrecognized dietary factor essential for reproduction. Science $56: 649-651$

Ge, S.Y., H.L. Luo, L.Y. Yan, and D.B. Yue. 2011. Effect of vitamin E supplementation in diet on meat quality of Aohan Fine-wool sheep. Chinese Journal of Animal Science 47:36-40.

Gentry, P.C., T.T. Ross, B.C. Oetting, and K.D. Birch. 1992. Effects of supplemental d-alpha-tocopherol on preweaning lamb performance, serum and colostrum tocopherol levels and immunoglobulin G titers. Sheep Research Journal 8:95-100.

Hou, J.C., F. Wang, Y.T. Wang, and F. Liu. 2012. Effects of vitamin E on the concentration of conjugated linoleic acids and accumulation of intermediates of ruminal biohydrogenation in vitro. Small Ruminant Research 1:63-70.

International Institute for Refrigeration. 1964. Recommendations for the handling of frozen foods. p. 112. Institut International du Froid, Paris, France.

Juárez, M., M.E.R. Dugan, J.L. Aalhus, N. Aldai, J.A. Basarab, V.S. Baron, et al. 2011. Effects of vitamin $E$ and flaxseed on rumen derived fatty acid intermediates in beef intramuscular fat. Meat Science 88:434-440.

Juárez, M., M.E.R. Dugan, N. Aldai, J.L. Aalhus, J.A. Basarab, V.S. Baron, et al. 2010. Dietary vitamin E inhibits the trans 10-18:1 shift in beef backfat. Canadian Journal of Animal Science 90:912 .

Kasapidou,E., M.Enser,J.D.Wood,R.I.Richardson, R.G.Wilkinson, and L.A. Sinclair. 2009. Influence of vitamin E supplementation and basal diet on the vitamin $\mathrm{E}$ status, performance and tissue fatty acid concentration in lambs. Animal 3:516-526.

Kasapidou, E., J.D. Wood, R.I. Richardson, L.A. Sinclair, R.G. Wilkinson, and M. Enser. 2012. Effect of vitamin E supplementation and diet on fatty acid composition and on meat colour and lipid oxidation of lamb leg steaks displayed in modified atmosphere packs. Meat Science 90:908-916.
Kolb, E., and J. Seehawer. 1998. The development of the immune system and vitamin levels in the bovine fetus and neonate: a review including the effect of vitamins on the immune system. Tierarztliche Umschau 53:723-730.

Lanza, M., M. Bella, D. Barbagallo, V. Fasone, L. Finocchiaro, and A. Priolo. 2003. Effect of partially or totally replacing soybean meal and maize by chickpeas (Cicer arietinum L.) in lamb diets: growth performance, carcass and meat quality. Animal Research $52: 263-270$

Liu, K., H.L. Luo, D.B. Yue, S.Y. Ge, F. Yuan, L.Y. Yan, et al. 2012. Molecular cloning and characterization of the sheep $\alpha$-TTP gene and its expression in response to different vitamin E status. Gene 494:225-230.

Luo, H.L., H. Meng, H. Zhu, and G.J. Zhang. 2010. The primary mechanism of effect of vitamin $\mathrm{E}$ on meat quality in goat. Feed Industry S2:57-63.

Macit, M., V. Aksakal, E. Emsen, M.I. Aksu, M. Karaoglu, and N. Esenbuga. 2003a. Effects of vitamin E supplementation on performance and meat quality traits of Morkaraman male lambs. Meat Science 63:51-55.

Macit, M., V. Aksakal, E. Emsen, N. Esenbuga, and M.I. Aksu. 2003b. Effects of vitamin E supplementation on fattening performance, non-carcass components and retail cut percentages, and meat quality traits of Morkaraman male lambs. Meat Science 64:1-6.

Maiorano, G., C. Cavone, R.J. McCormick, A. Ciarlariello, M. Gambacorta, and A. Manchisi. 2007. The effect of dietary energy and vitamin $\mathrm{E}$ administration on performance and intramuscular collagen properties of lambs. Meat Science 76:182-188.

Mitsumoto, M., S. Ozawa, T. Mitsuhashi, and K. Koide. 1998. Effect of dietary vitamin E supplementation for one week before slaughter on drip, color and lipid stability during display in Japanese black steer beef. Meat Science 49:165-174.

Morrisey, P.A., D.J. Buckley, P.J.A. Sheehy, and F.J. Monahan. 1994. Vitamin E and meat quality. Proceedings of the Nutrition Society $53: 289-295$

NRC. 1985. Nutrient requirements of sheep. National Research Council (NRC), Washington, D.C., USA.

Ponnampalam, E.N., A.J. Sinclair, A.R. Egan, S.J. Blakeley, and B.J. Leury. 2001. Effect of diets containing n-3 fatty acids on muscle long-chain n-3 fatty acid content in lambs fed low- and mediumquality roughage diets. Journal of Animal Science 79:698-706.

Pottier, J., M. Focant, C. Debier, G. De Buysser, C. Goffe, E. Mignolet, et al. 2006. Effect of dietary vitamin E on rumen biohydrogenation pathways and milk fat depression in dairy cows fed high-fat diets. Journal of Dairy Science 89:685-692.

Salvatori, G., L. Pantaleo, C. Di Cesare, G. Maiorino, F. Filetti, and G. Oriani. 2004. Fatty acid composition and cholesterol content of muscles as related to genotype and vitamin $\mathrm{E}$ treatment in crossbred lambs. Meat Science 67:45-55.

SAS Institute. 2002. SAS User's guide: Statistics. SAS Institute, Cary, North Carolina, USA.

Sherbeck, J.A., D.M. Wulf, J.B. Morgan, J.D. Tatum, G.C. Smith, and S.N. Williams. 1995. Dietary supplementation of vitamin E to feedlot cattle affects beef retail display properties. Journal of Food Science 60:250-252.

Turner, K.E., K.E. McClure, W.P. Weiss, R.J. Borton, and J.G. Foster. 2002. Alpha-tocopherol concentrations and case life of lamb muscle as influenced by concentrate or pasture finishing. Journal of Animal Science 80:2513-2521.

Van Soest, P.J., J.B. Robertson, and B.A. Lewis. 1991. Methods for dietary fiber, neutral detergent fiber, and non-starch polysaccharides in relation to animal nutrition. Journal of Dairy Science 74:3583-3592.

Wulf, D.M., J.B. Morgan, S.K. Sanders, J.D. Tatum, G.C. Smith, and S. Williams. 1995. Effects of dietary supplementation of vitamin E on storage and caselife properties of lamb retail cuts. Journal of Animal Science 73:399-405

Yan, L.Y., D.B. Yue, H.L. Luo, X.X. Jin, and X. Xu. 2010. Effect of vitamin $\mathrm{E}$ supplementation on the enzymatic activity of selected markers in Aohan fine-wool sheep testis. Animal Reproduction Science 122:264-269. 